46 Nemeroff $\mathrm{CB}$, Vale WW. The neurobiology of depression: inroads to treatment and new drug discovery. J Clin Psychiatry 2005; 66: 5-13.

47 O'Keane V, Lightman S, Marsh M, Pawlby S, Papadopoulos AS, Taylor A, et al. Increased pituitary-adrenal activation and shortened gestation in a sample of depressed pregnant women: a pilot study. J Affect Disord 2011; 130: 300-5.

48 Coussons-Read ME, Okun ML, Nettles CD. Psychosocial stress increases inflammatory markers and alters cytokine production across pregnancy. Brain Behav Immun 2007; 21: 343-50.

49 Jung C, Ho JT, Torpy DJ, Rogers A, Doogue M, Lewis JG, et al. A longitudina study of plasma and urinary cortisol in pregnancy and postpartum. J Clin Endocrinol Metab 2011; 96: 1533-40.

50 Alhusen JL. A literature update on maternal-fetal attachment. J Obstet Gynecol Neonatal Nurs 2008; 37: 315-28.

51 Stronach EP, Toth SL, Rogosch F, Oshri A, Manly JT, Cicchetti D. Child maltreatment, attachment security, and internal representations of mother and mother-child relationships. Child Maltreat 2011; 16: 137-45.

52 Feldman R, Weller A, Zagoory-Sharon O, Levine A. Evidence for a neuroendocrinological foundation of human affiliation: plasma oxytocin levels across pregnancy and the postpartum period predict mother-infant bonding. Psychol Sci 2007; 18: 965-70.
53 Ge X, Conger RD, Cadoret RJ, Neiderhiser JM, Yates W, Troughton E. The developmental interface between nature and nurture: a mutual influence model of child antisocial behavior and parent behaviors. Dev Psychol 1996; 32: $574-89$.

54 Hatch SL, Woodhead C, Frissa S, Fear NT, Verdecchia M, Stewart R, et al. Importance of thinking locally for mental health: data from cross-sectional surveys representing South East London and England. PLOS One 2012; 7: e48012.

55 Silberg JL, Maes H, Eaves $\amalg$. Genetic and environmental influences on the transmission of parental depression to children's depression and conduct disturbance: an extended Children of Twins study. J Child Psychol Psychiatry 2010; 51: 734-44

56 World Health Organization. Mental Disorders: Glossary and Guide to Their Classification in Accordance with the 9th Revision. World Health Organization Press, 1978.

57 National Collaborating Centre for Mental Health. Antenatal and Postnata Mental Health: Clinical Management and Service Guidance. NICE Clinical Guidelines, No. 45. The British Psychological Society, 2007.

58 Ross LE, Grigoriadis S, Mamisashvili L, Vonderporten EH, Roerecke M, Rehm J, et al. Selected pregnancy and delivery outcomes after exposure to antidepressant medication: a systematic review and meta-analysis. JAMA Psychiatry 2013; 70: 436-43.

\title{
psychiatry in the movies
}

\section{Waltz with Bashir (2008; director/writer: Ari Folman)}

\section{Jeremy Rampling}

Ari Folman's Waltz with Bashir is an animated documentary about the 1982 Lebanon War through the eyes of Israeli Defence Forces (IDF) veterans. The narrative, which follows Folman on a quest to uncover his lost memories of the War through interviews with his peers, plays out like psychotherapeutic intervention; Folman questions his own responsibilities, his hereditary scars and, ultimately, his guilt as he 'unwillingly [takes on] the role of the Nazi'. While it would be disingenuous to call the film apolitical, it is not as political as one might expect from such evocative history. Rather, it is a treatise on memory and psychological survival through predominantly neurotic defence mechanisms.

The film opens with another veteran's recurrent nightmare of the snarling dogs he was seconded to kill some 25 years before. Folman's realisation that much of his wartime experience is 'not stored in my system' triggers his own flashback - an eerily beautiful, ethereal scene in which the young IDF are bathing nude in the Mediterranean while golden flares light up the Beirut sky. We discover with Folman that this is a false memory; in fact, he was part of a team shooting flares to facilitate the Phalange massacre at Sabra and Shatila.

Folman questions both why this dream should trigger his own flashback and the creation of false memories. We hear memory described as 'dynamic ... alive. If some details are missing, memory fills the hole with things that never happened' while Professor Zahava Solomon of Tel Aviv University explains dissociation, emphasising both its function and its fragility. We also hear from a veteran plagued by his memories of an ambush on his troop in which he was the sole survivor. For him, memory is a curse and amnesia would be welcomed.

Folman also shows us the importance of context, perception and appraisal in memory, a valid tenet in PTSD theory. A character, carried away by the emotion of going to war, recalls his transport to Beirut as a 'love boat' only to discover later that it was a routine converted commando ship. Two scenes of violence, one involving the death of a child soldier, are made gentle by delicate classical music while a fantasy scene in a bombed-out Beirut airport again tells of the unreliability of the human source. The final segue from animation into actual footage of Palestinian widows and indiscriminate corpses is perhaps the most reliable historical account of the film, underlining the all-too-real documentary that lies behind the cartoon.

We must emphasise that Folman himself is not suffering from a psychiatric disorder. He is untroubled by nightmares, flashbacks or hyperarousal but instead by an intellectual curiosity into the selectivity of the mind. The film reminds us that not all primitive defence mechanisms need be pathological, indeed the majority allow survival of the mental self in the face of extreme trauma or guilt. In this deeply personal film, Ari Folman has exposed the guilt of his ineffective 19-year-old self and has made a public request for forgiveness. 